\title{
Article \\ Anodic Oxidation of Industrial Winery Wastewater Using Different Anodes
}

\author{
Yeney Lauzurique ${ }^{1,2}$ (D) Lidia Carolina Espinoza ${ }^{3}$, César Huiliñir $^{1}$, Verónica García ${ }^{4}$ and Ricardo Salazar ${ }^{2, *}$ (D) \\ 1 Laboratorio de Biotecnología Ambiental, Facultad de Ingeniería, Universidad de Santiago de Chile, \\ Ave. Libertador Bernardo O’Higgins 3363, Santiago de Chile 9160000, Chile; yeney.lauzurique@usach.cl (Y.L.); \\ cesar.huilinir@usach.cl (C.H.) \\ 2 Laboratorio de Electroquímica del Medio Ambiente, Facultad de Química y Biología, Universidad de \\ Santiago de Chile, Santiago de Chile 9160000, Chile \\ 3 Centro de Investigación de Procesos Redox (CIPREx), Laboratorio Biosensores, Facultad de Ciencias Químicas \\ y Farmacéuticas, Universidad de Chile, Santiago de Chile 9160000, Chile; carolina.espinoza@ciq.uchile.cl \\ 4 Laboratorio de Microbiología, Facultad Tecnológica, Universidad de Santiago de Chile, \\ Santiago de Chile 9160000, Chile; veronica.garcia@usach.cl \\ * Correspondence: ricardo.salazar@usach.cl; Tel.: +56-2-7181134
}

Citation: Lauzurique, Y.; Espinoza, L.C.; Huiliñir, C.; García, V.; Salazar, R. Anodic Oxidation of Industrial Winery Wastewater Using Different Anodes. Water 2022, 14, 95 . https:// doi.org/10.3390/w14010095

Academic Editor: Chengyun Zhou

Received: 21 October 2021

Accepted: 29 December 2021

Published: 4 January 2022

Publisher's Note: MDPI stays neutral with regard to jurisdictional claims in published maps and institutional affiliations.

Copyright: (c) 2022 by the authors. Licensee MDPI, Basel, Switzerland. This article is an open access article distributed under the terms and conditions of the Creative Commons Attribution (CC BY) license (https:// creativecommons.org/licenses/by/ $4.0 /)$.

\begin{abstract}
Winery wastewater represents the largest waste stream in the wine industry. This deals with the mineralization of the organic matter present in winery wastewater using anodic oxidation and two types of anodes-namely, a boron-doped diamond electrode (BDD) and two mixed metal oxides (MMO), one with the nominal composition $\mathrm{Ti} / \mathrm{Ru}_{0.3} \mathrm{Ti}_{0.7} \mathrm{O}_{2}$ and the other with $\mathrm{Ti} / \mathrm{Ir}_{0.45} \mathrm{Ta}_{0.55} \mathrm{O}_{2}$. To conduct the study, the variability of different quality parameters for winery wastewater from the Chilean industry was measured during eight months. A composite sample was treated using anodic oxidation without the addition of supporting electrolyte, and the experiments were conducted at the natural $\mathrm{pH}$ of the industrial wastewater. The results show that this effluent has a high content of organic matter (up to $3025 \pm 19 \mathrm{mg} / \mathrm{L}$ of total organic carbon (TOC)), which depends on the time of the year and the level of wine production. With MMO electrodes, TOC decreased by $2.52 \%$ on average after $540 \mathrm{~min}$, which may be attributed to the presence of intermediate species that could not be mineralized. However, when using a BDD electrode, $85 \%$ mineralization was achieved due to the higher generation of hydroxyl radicals. The electrolyzed sample contained oxamic, acetic, and propionic acid as well as different ions such as sulfate, chloride, nitrate, and phosphate. These ions can contribute to the formation of different species such as active species of chlorine, persulfate, and perphosphate, which can improve the oxidative power of the system.
\end{abstract}

Keywords: winery wastewater; anodic oxidation; BDD and MMO electrodes; hydroxyl radicals; ions

\section{Introduction}

Winery wastewater is mainly the result of a series of activities such as the cleaning of barrels and tanks, washing of transfer lines and floors, wine loss and extraction, and processes in filtration units and water drains from the wastewater management system [1-3]. Therefore, depending on factors that range from the size of the facility to production and cleaning methods, between one and four liters of residual water are generated per liter of wine produced $[4,5]$.

In general, this industrial effluent has a high organic load that may lead to contamination if not treated correctly [6]. In addition, winery wastewater has a high concentration of suspended solids, low content of nutrients, and recalcitrant high molecular weight compounds such as polyphenols, fertilizers, and pesticides [7-10]. These compounds are not easily removed by the biological processes normally used to treat this type of wastewater, which makes it difficult to achieve a high removal of organic matter [11,12]. In order to efficiently eliminate these compounds, some authors have used advanced oxidation processes (AOPs) in which highly reactive oxygen species are generated in situ $[7,13]$. AOPs 
based on electrochemical technology, known as electrochemical advanced oxidation processes (EAOPs), are a powerful tool for effectively removing organic matter from industrial wastewater [14].

EAOPs are environmentally friendly due to their low reagent requirements. Furthermore, they have high energy efficiency and low operating costs, provide rapid kinetics in the decomposition of different pollutants, and are safe under working conditions [15-18]. Among EAOPs, one of the most widely proposed and used has been anodic oxidation (AO) $[14,19-23]$ due to its versatility, simplicity, and easy scalability [24]. According to Espinoza, et al. [25], this process can be implemented alone or as a pre- or post-treatment for other physicochemical and biological processes. In this way, it is possible to increase the electrode yield, reduce energy demand, and decrease water toxicity. In the AO process, the oxidation of organic contaminants can occur directly or indirectly depending on the nature of the anode [21,26]. In this sense, Comninellis and Chen [27] define two types of anode surfaces: (i) active and (ii) non-active. In both cases, the electrochemical discharge of water occurs on the surface of the anode $(\mathrm{M})$, generating hydroxyl radicals $\left({ }^{\circ} \mathrm{OH}, \mathrm{E}^{\circ}=2.80 \mathrm{~V} / \mathrm{SHE}\right.$ ) that remain physisorbed on the surface of the anode (reaction (1)). Nevertheless, active anodes have low overpotential for oxygen evolution and high adsorption enthalpies; therefore, the ${ }^{\bullet} \mathrm{OH}$ formed can strongly interact with the anode surface, forming metal oxides (MO) or higher state superoxide by means of reaction (2). Subsequently, the redox couple $(\mathrm{MO} / \mathrm{M})$ acts as a mediator in the partial oxidation of organic pollutants (R), regenerating the metallic surface $M$ by reaction (3). On the contrary, non-active anodes are characterized by high overpotentials for oxygen evolution and low adsorption enthalpies, which leads to ${ }^{\bullet} \mathrm{OH}$ weakly adhering to the anode surface. In this case, ${ }^{\bullet} \mathrm{OH}$ reacts with the organic compounds until their complete mineralization to carbon dioxide $\left(\mathrm{CO}_{2}\right)$, water $\left(\mathrm{H}_{2} \mathrm{O}\right)$, and inorganic ions (reaction (4)).

$$
\begin{gathered}
\mathrm{M}+\mathrm{H}_{2} \mathrm{O} \rightarrow \mathrm{M}\left({ }^{\bullet} \mathrm{OH}\right)+\mathrm{H}^{+}+\mathrm{e}^{-} \\
\mathrm{M}\left({ }^{\bullet} \mathrm{OH}\right) \rightarrow \mathrm{MO}+\mathrm{H}^{+}+\mathrm{e}^{-} \\
\mathrm{MO}+\mathrm{R} \rightarrow \mathrm{RO}+\mathrm{M} \\
\mathrm{aM}\left({ }^{\bullet} \mathrm{OH}\right)+\mathrm{R} \rightarrow \mathrm{aM}+\mathrm{mCO}_{2}+\mathrm{nH}_{2} \mathrm{O}+\mathrm{xH}^{+}+\mathrm{ye}^{-}
\end{gathered}
$$

Among active anodes, mixed metal oxides (MMO) stand out. These anodes are based on mixed metal oxides of ruthenium $(\mathrm{Ru})$, titanium $(\mathrm{Ti})$, tantalum $(\mathrm{Ta})$, antimony $(\mathrm{Sb})$, or tin $(\mathrm{Sn})$ in different proportions and supported on a Ti sheet $[15,19]$. They exhibit high stability, activity, excellent durability, and are easy to scale for industrial purposes $[20,26,28]$. In contrast, boron-doped diamond (BDD) thin-film electrodes are considered non-active anodes. These anodes have high corrosion stability and therefore can be used in strongly acidic environments. In addition, the weak interaction between ${ }^{\circ} \mathrm{OH}$ and its surface, together with its high overpotential for oxygen evolution, is favorable for the generation of greater amounts of $\mathrm{M}\left({ }^{\bullet} \mathrm{OH}\right)$ with the capacity to mineralize persistent organic compounds in water $[17,29,30]$.

It is known that the $\mathrm{AO}$ process does not present restrictions in terms of $\mathrm{pH}$ [18] and that it is not easily influenced by temperature [31]. However, in many cases, the addition of a supporting electrolyte is required [32] to improve the conductivity of the solution and contribute to reducing the cost of energy. In this sense, several types of industrial wastewater contain sulfates, chlorides, phosphates, and oxygen, which contribute to the formation of oxidants such as persulfate $\left(\mathrm{S}_{2} \mathrm{O}_{8}{ }^{2-}\right)$, active chlorine species $\left(\mathrm{Cl}_{2}, \mathrm{HClO}\right.$, $\left.\mathrm{ClO}^{-}\right)$, perphosphate $\left(\mathrm{P}_{2} \mathrm{O}_{8}{ }^{4-}\right)$, and hydrogen peroxide $\left(\mathrm{H}_{2} \mathrm{O}_{2}\right)$, respectively [31]. This indicates that the use of agents present in the solution to be treated could be sufficient to improve conductivity and promote the generation of oxidizing species, simplifying the AO process by not having to add salts, which can also make the process more expensive.

There is a limited number of reports that have compared the efficiency of different electrocatalytic materials during the $\mathrm{AO}$ process in different electrolytic media [21,33-36]. 
Nevertheless, there are no studies in which the efficiency of different electrocatalytic materials is compared in the $\mathrm{AO}$ of real winery water and without the addition of supporting electrolytes. Therefore, the objective of this work is to study the electrochemical mineralization of a sample composed of real winery wastewater containing $1349 \pm 25.24 \mathrm{mg} / \mathrm{L}$ of total organic carbon (TOC) under electrolysis at constant current density without the addition of a supporting electrolyte and using three anodic materials (BDD, $\mathrm{MMO}-\mathrm{Cl}_{2}$, and MMO-O $\mathrm{O}_{2}$ ). Moreover, the winery wastewater of a Chilean industry was monitored in order to find a representative sample to conduct the electrochemical experiments. Degradation of the organic compounds present in the wastewater was followed by spectrophotometric (decrease in maximum absorbance, turbidity) and chromatographic techniques (decay of specific pollutants present in the wastewater), while mineralization was measured through TOC decay. This study contributes with the application of AO for the treatment of real industrial wastewater, making the process simpler and more competitive, as it would not be necessary to adjust $\mathrm{pH}$ or add a supporting electrolyte.

\section{Materials and Methods}

\subsection{Winery Wastewater}

Winery wastewater was obtained between April and November 2018 from a Chilean wine industry located in Santiago de Chile. This period includes the vintage and the nonvintage stages; therefore, it allows studying the behavior of the industry and its wastewater under different real parameters (high and low polluting loads). The 22 samples were collected before the aerobic biological process in the industrial wastewater treatment plant and refrigerated at $4{ }^{\circ} \mathrm{C}$ for further characterization.

To carry out the electrochemical experiments, a composite sample made from the samples collected during October and November was employed. The results of the characterization of the composite sample (used in the electrochemical treatment) are shown in Table 1. In general, the sample shows a high content of organic matter, low concentrations of nitrogen and phosphorus compounds, low $\mathrm{pH}$, and an unpleasant odor. In addition, it should be noted that although the initial turbidity of the sample was $321 \pm 0.20 \mathrm{NTU}$, this parameter was reduced by approximately $96 \%$ after centrifuging the sample.

Table 1. Parameters of composite sample.

\begin{tabular}{|c|c|}
\hline Parameters & Results \\
\hline Color & Light red \\
\hline Odor & Intense \\
\hline $\mathrm{pH}$ & $4.28 \pm 0.16$ \\
\hline Conductivity (mS) & $2.60 \pm 0.04\left(\mathrm{~T}=25.80^{\circ} \mathrm{C}\right)$ \\
\hline Turbidity (NTU) & $12.30 \pm 1.50$ \\
\hline Total organic carbon $(\mathrm{mg} / \mathrm{L})$ & $1349 \pm 25.24$ \\
\hline Soluble chemical oxygen demand (mg/L) & $4140 \pm 28.28$ \\
\hline Biochemical oxygen demand $(\mathrm{mg} / \mathrm{L})$ & $2678 \pm 20.16$ \\
\hline Absorbance at $254 \mathrm{~nm}$ (U.A) & $0.65 \pm 0.01$ \\
\hline Nitrate $\left(\mathrm{mg} \mathrm{NO}_{3}^{-} / \mathrm{L}\right)$ & $0.40 \pm 0.05$ \\
\hline Phosphate $\left(\mathrm{mg} \mathrm{PO}_{4}{ }^{3-} / \mathrm{L}\right)$ & $24 \pm 2.46$ \\
\hline Chloride $\left(\mathrm{mg} \mathrm{Cl}^{-} / \mathrm{L}\right)$ & $364 \pm 1.73$ \\
\hline Sulfate $\left(\mathrm{mg} \mathrm{SO}_{4}{ }^{2-} / \mathrm{L}\right)$ & $142 \pm 2.92$ \\
\hline Acetic acid $(\mathrm{mg} / \mathrm{L})$ & $2463 \pm 69.64$ \\
\hline Propionic acid $(\mathrm{mg} / \mathrm{L})$ & $356 \pm 22.24$ \\
\hline Fecal Coliforms Lecture (NMP/100 mL) & $\geq 1.60 \times 10^{4}$ \\
\hline
\end{tabular}

\subsection{Experimental Procedure}

Winery wastewater was treated through the $\mathrm{AO}$ process without the addition of salts as a supporting electrolyte at the original $\mathrm{pH}$ value and at room temperature. Electrolysis was performed in an undivided $0.10 \mathrm{~L}$ open cell by vigorously stirring in order to ensure mass transfer (Figure 1). Three different electrodes were used as anodes: (1) a boron-doped 
diamond (BDD) electrode supplied by Adamant Technologies, which had a 2.75-thick diamond layer doped with a concentration of 500 ppm of boron, (2) a mixed metal oxide (MMO-Cl 2 type: nominal composition $\mathrm{Ti} / \mathrm{Ru}_{0.3} \mathrm{Ti}_{0.7} \mathrm{O}_{2}$ ), and (3) a mixed metal oxide (MMO$\mathrm{O}_{2}$ type: nominal composition $\mathrm{Ti} / \mathrm{Ir}_{0.45} \mathrm{Ta}_{0.55} \mathrm{O}_{2}$ ) both from NMT Electrodes PTY LTD (Pinetown, South Africa). A stainless-steel plate (AISI 304) was used as the cathode for each electrolysis. The electrodes had a geometric area of $5 \mathrm{~cm}^{2}$, with an inter-electrode gap of $1 \mathrm{~cm}$. All the experiments were performed twice applying a current density of $30 \mathrm{~mA} / \mathrm{cm}^{2}$. To remove impurities from the surfaces of the cathode and anode, the electrodes were

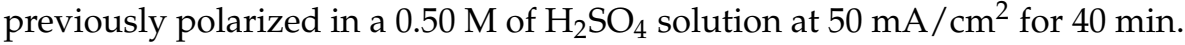

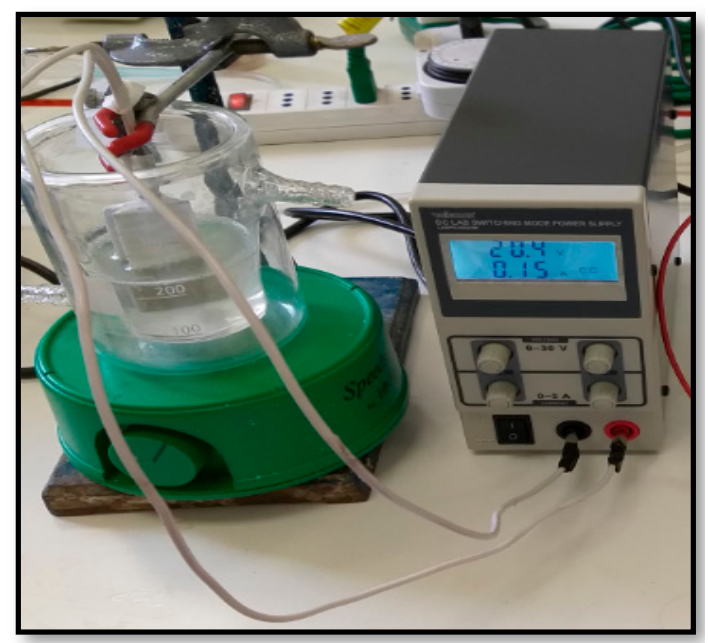

Figure 1. Electrochemical system.

\subsection{Apparatus and Analytical Procedures}

The winery wastewater samples were centrifuged in order to reduce the solids in suspension. Electrolyses were performed using an MCP model M10-QD305 power supply, which provides the constant current to conduct electrolysis in galvanostatic mode and to deliver a potential difference between anode and cathode. During electrolysis, samples were always withdrawn from the same solution kept in the cell at regular time intervals and then refrigerated at $4{ }^{\circ} \mathrm{C}$ until analysis. The degradation of the organic compounds present in the wastewater was followed by spectrophotometric techniques, and mineralization was studied through TOC removal. This parameter was obtained using a Shimadzu model TOC-L analyzer.

Soluble chemical oxygen demand (sCOD) was measured using reactive HANNA COD tube tests HI 93754B-25 (range 0-1500 mg/L). The samples were chemically digested for $2 \mathrm{~h}$ at $150 \pm 1{ }^{\circ} \mathrm{C}$ in a HANNA Instruments HI 839800 digestor and analyzed in a photometer HANNA Instruments HI 83214.

Total suspended solids (TSS), volatile suspended solids (VSS), and alkalinity were also measured according to the Standard Methods for the Examination of Water and Wastewater [37], as well as the 5-day biochemical oxygen demand (BOD 5$)$, for which a dissolved oxygen meter analyzer Milwaukee, MW 600 model, was employed.

Absorbance decay at $254 \mathrm{~nm}$ was monitored in an Agilent model 8453 spectrophotometer. Water turbidity expressed as NTU (nephelometric units of turbidity) was measured using an HI 98703 Turbidimeter. A Lutron model pH-222 pH-meter was used to calculate $\mathrm{pH}$. Conductivity was measured using a HANNA Instruments HI 98312 Multiparameter Meter. The presence of fecal coliforms was quantified through the NMP procedure and using the A-1 method [38].

Carboxylic acids were identified and quantified by ion exclusion chromatography. Aliquots were analyzed on a Shimadzu LC-20AD UFLC with a Shimadzu SPD-M20A diode array detector, which was equipped with a BIO-RAD Aminex HPX-87H $300 \mathrm{~mm} \times 7.8 \mathrm{~mm}$ 
(i.d) ion exclusion column. The wavelength was set at $210 \mathrm{~nm}$, and $4 \mathrm{mM} \mathrm{H}_{2} \mathrm{SO}_{4}$ was used as a mobile phase with a flow of $0.60 \mathrm{~mL} / \mathrm{min}$ at $35^{\circ} \mathrm{C}$.

Inorganic ions $\left(\mathrm{Cl}^{-}, \mathrm{PO}_{4}{ }^{3-}, \mathrm{SO}_{4}{ }^{2-}, \mathrm{NO}_{3}{ }^{-}\right)$were determined by ion chromatography using a 930 Compact IC Flex-Metrohm after filtering the samples through $0.22 \mu \mathrm{m}$ MLC disposable syringe filter. A Metrosep A Supp 5-250/4.0 column was used with $3.20 \mathrm{mM}$ of sodium carbonate as eluent in a flow of $0.70 \mathrm{~mL} / \mathrm{min}$. The total ammonia nitrogen content, expressed as $\mathrm{mg} \mathrm{N}-\mathrm{NH}_{4}{ }^{+} / \mathrm{L}$, was quantified using a QuikChem 8500 Series 2 FIA system.

In order to compare the experimental data, $t$-test Two Sample Assuming Equal Variances were carried out using Excel 2110.

\section{Results and Discussion}

\subsection{Characterization of Real Winery Wastewater in a Long Period}

Figure 2 shows the results of the characterization obtained during the months of monitoring in terms of organic matter $\left(\mathrm{sCOD}_{1} \mathrm{BOD}_{5}\right.$, and TOC) and solids. $\mathrm{SCOD}, \mathrm{BOD}_{5}$, and TOC show the high content of organic matter that is typical for this type of wastewater [39]. The $\mathrm{BOD}_{5} / \mathrm{sCOD}$ ratio for winery wastewater was in the order of 0.54 to 0.73 . This result demonstrates the high biodegradability of these waters and agrees with other values reported in the literature $[40,41]$.

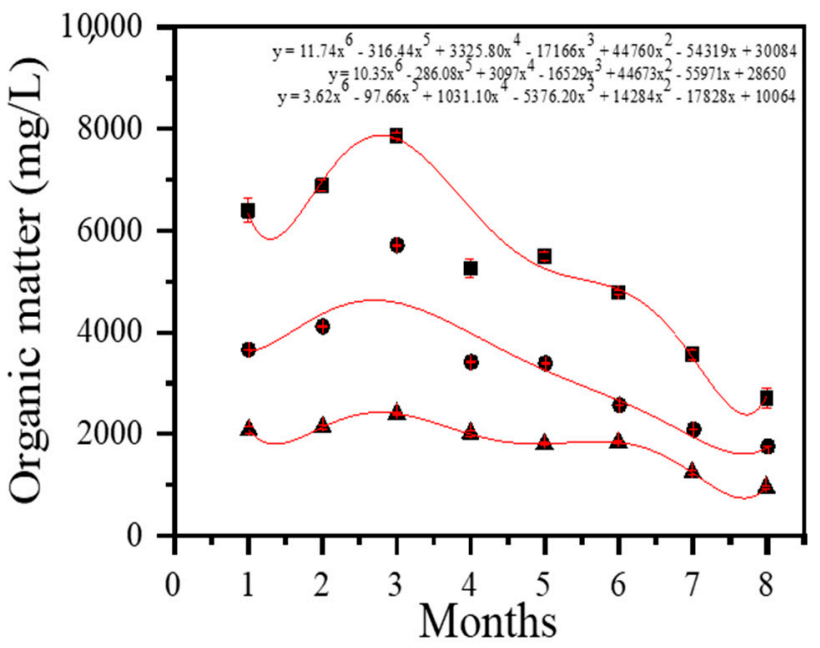

(a)

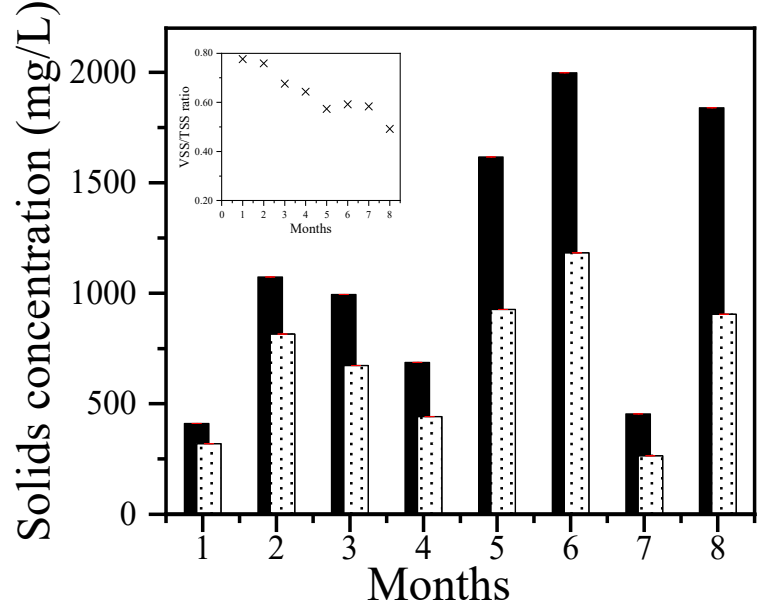

(b)

Figure 2. Characterization of winery wastewater during eight months of monitoring, (a) content of organic matter $(\mathbf{\square})$ sCOD, $(\bullet)$ BOD $_{5},(\boldsymbol{\Delta})$ TOC, polynomial fit; (b) concentration of solids ( $\left.\mathbf{\square}\right)$ TSS, (i) VSS, (X) VSS/TSS ratio. Specification: the values of the parameters correspond to the average value of the parameter according to the samples collected in each month.

Figure $2 \mathrm{a}$ shows that the highest $\mathrm{SCOD}, \mathrm{BOD}_{5}$, and TOC concentrations were obtained between April and June (Months 1-3), with values as high as $7863 \pm 50 \mathrm{mg} / \mathrm{L}$ in the case of $\mathrm{sCOD}, 5720 \pm 11 \mathrm{mg} / \mathrm{L}$ for $\mathrm{BOD}_{5}$, and $2405 \pm 19 \mathrm{mg} / \mathrm{L}$ in the case of TOC. Subsequently, the values of sCOD, BOD 5 , and TOC decreased by approximately $4361 \mathrm{mg} / \mathrm{L}, 2649 \mathrm{mg} / \mathrm{L}$, and $1574 \mathrm{mg} / \mathrm{L}$, on average, respectively. This indicates that during and immediately after vintage, wastewater contains the highest concentration of organic matter. However, it should be noted that sometimes, a slight increase in organic load may occur sporadically (as in the sample collected in August (Month 5)). According to [42], this is related to the pressing and refiltration of newly fermented wine.

Regarding the presence of solids in wastewater, the situation was different (Figure 2b). Solids concentration did not show a special high value around vintage. Indeed, the average values of TSS and VSS were $827 \mathrm{mg} / \mathrm{L}$ and $602 \mathrm{mg} / \mathrm{L}$, respectively, between April and June (Months 1-3), while between July and November (Months 4-8), the average values of TSS and VSS were $1319 \mathrm{mg} / \mathrm{L}$ and $744 \mathrm{mg} / \mathrm{L}$. The highest solid concentration was observed in 
September (1998 $\pm 0.05 \mathrm{mg} / \mathrm{L}$, month 6), during the non-vintage period, with a VSS/TSS ratio equal to 0.59 .

According to these analyses, winery wastewater presents variable concentrations of sCOD between $3560 \pm 94$ and $7863 \pm 50 \mathrm{mg} / \mathrm{L}$, as well as TOC $(957 \pm 20$ and $2405 \pm 19 \mathrm{mg} / \mathrm{L})$, and a high content of easily biodegradable organic matter $\left(\mathrm{BDO}_{5}\right.$ between $1760 \pm 2$ and $5720 \pm 11 \mathrm{mg} / \mathrm{L}$ ). In addition, regarding the concentration of solids, it is noteworthy that the samples were collected after three physical filtration units that reduced most of the suspended solids.

These results demonstrate the seasonality of this type of wastewater, which is directly related to the period of work (vintage or non-vintage period) and the type of wine produced (red, white, sparkling, special wines, etc.) [39]. In this sense, wastewater generated during vintage has a higher flow rate and organic content than the water produced during the rest of the year $[4,43]$. Regarding the type of wine, Montalvo, et al. [44] found that wastewater from the production of red wine usually contains ethanol, carbohydrates, organic acids, and polyphenols, while wastewater from tropical fruits wine has a high sugar content and sulfur compounds. Likewise, Braz, et al. [45] studied the characterization of winery wastewater from two Portuguese wineries and found that wastewaters from the production of red wine present a greater amount of organic matter and suspended solids than wastewaters from the production of white wine. As it may be seen, this variability causes significant fluctuations in the quantity and quality of this effluent. Therefore, several authors currently propose EAPOs to treat winery wastewater $[8,14,40]$.

Table 2 shows the behavior of other wastewater parameters measured over time. The samples presented color differences, which is related to the type of wine produced and mostly due to the natural colors of grapes [12]. In this sense, the spectrum exhibited a band at $254 \mathrm{~nm}$, which might correspond to different organic compounds that absorb in this wavelength region. Candia-Onfray, et al. [14] observed a characteristic band at $280 \mathrm{~nm}$, which they associated mainly with the presence of polyphenols but also with other organic compounds such as acetic acid, butyl ester, ethylbenzene, cyclohexanol, ethanol, and isopropyl stearate, among others.

Table 2. Parameters monitored in winery wastewater over time.

\begin{tabular}{|c|c|c|c|c|c|c|c|c|}
\hline Parameters & April & May & Jun & July & August & September & October & November \\
\hline Color & Light red & Orange & Yellow & Orange & Brown & Brown & Brown & Brown \\
\hline Odor & Intense & Intense & Intense & Intense & Intense & Intense & Intense & Intense \\
\hline $\mathrm{pH}$ & 6.30 & 9.30 & 6.95 & 9.23 & 9.38 & 8.10 & 8.42 & 11.34 \\
\hline $\begin{array}{l}\text { Total alkalinity (mg } \\
\left.\mathrm{CaCO}_{3} / \mathrm{L}\right)\end{array}$ & 493 & 1534 & 817 & 2257 & 1091 & 998 & 468 & 2309 \\
\hline $\begin{array}{l}\text { Partial alkalinity (mg } \\
\left.\qquad \mathrm{CaCO}_{3} / \mathrm{L}\right)\end{array}$ & 240 & 934 & 501 & 1619 & 715 & 583 & 319 & 1887 \\
\hline Turbidity (NTU) & 234 & 463 & 500 & 286 & 555 & 821 & 317 & 782 \\
\hline $\begin{array}{c}\text { Absorbance at } 254 \mathrm{~nm} \\
\text { (U.A) }\end{array}$ & 1.20 & 2 & 0.79 & 1.39 & 0.76 & 0.60 & 1.31 & 0.87 \\
\hline Conductivity (mS) & 1.98 & 4.16 & 2.95 & 4 & 3.21 & 3.54 & 3.24 & 2.38 \\
\hline $\begin{array}{l}\text { Total ammonia nitrogen } \\
\qquad\left(\mathrm{mg} \mathrm{N}^{-\mathrm{NH}_{4}^{+}}{ }^{+} / \mathrm{L}\right)\end{array}$ & 1.02 & 3.94 & 1.09 & 1.20 & 0.63 & 2.41 & 3.07 & 1.57 \\
\hline Nitrate $\left(\mathrm{mg} \mathrm{NO}_{3}-/ \mathrm{L}\right)$ & 4.20 & 3.01 & 2.08 & 6 & 1.47 & 3.93 & 4.33 & 2 \\
\hline $\begin{array}{c}\text { Phosphate (mg } \\
\left.\mathrm{PO}_{4}{ }^{3-} / \mathrm{L}\right)\end{array}$ & 15.60 & 20.54 & 14.73 & 27.73 & 27.20 & 27.60 & 27.08 & 26.42 \\
\hline Chloride $\left(\mathrm{mg} \mathrm{Cl}^{-} / \mathrm{L}\right)$ & 350 & 919 & 388 & 832 & 1020 & 968 & 927 & 861 \\
\hline $\begin{array}{l}\text { Fecal Coliforms Lecture } \\
\text { NMP/100 mL }\end{array}$ & $\geq 1.60 \times 10^{3}$ & $>6 \times 10^{4}$ & $>9 \times 10^{3}$ & $7 \times 10^{4}$ & $2.90 \times 10^{4}$ & $1.05 \times 10^{5}$ & $4 \times 10^{4}$ & $1.60 \times 10^{5}$ \\
\hline
\end{tabular}

Specification: the values of the parameters correspond to the average value of the parameter according to the samples collected in each month.

Winery wastewater also presented a strong smell attributed to the production process and the presence of fecal coliforms $\left(\geq 1.60 \times 10^{3} \mathrm{NMP} / 100 \mathrm{~mL}\right)$. These microorganisms may originate from dirty grapes and water used for floor cleaning.

The concentrations of $\mathrm{CaCO}_{3}$ varied between 468 and $2309 \mathrm{mg} / \mathrm{L}$, displaying the highest values in May, July, and November. The values obtained for $\mathrm{pH}$ are within the 
established range for this type of effluent [39], with the lowest values during vintage. Conversely, the highest values are reported during the non-vintage period, which is related to cleanings carried out with sodium hydroxide $(\mathrm{NaOH})$. These results are in accordance with those obtained by Milani, et al. [46] in Italian wineries.

Turbidity showed values between 234 and 821 NTU. This parameter is associated with the presence of suspended and dissolved particles [14]. In this sense, the turbidity values obtained are consistent with the concentration of suspended solids, where the higher concentration of TSS (1998 $\pm 0.05 \mathrm{mg} / \mathrm{L})$ is related to higher turbidity (821 NTU).

The conductivity values were associated with the presence of $\mathrm{NH}_{4}{ }^{+}, \mathrm{NO}_{3}{ }^{-}, \mathrm{SO}_{4}{ }^{2-}$, $\mathrm{PO}_{4}{ }^{3-}, \mathrm{Cl}^{-}$, and other elements in wastewater. Table 2 shows that all the samples contain high concentrations of chloride, but it is evident that this type of water presents a deficit of nutrients (especially nitrate), which is consistent with other studies [47].

\subsection{Anodic Oxidation of Winery Wastewater}

Several electrolyses were performed to treat $0.10 \mathrm{~L}$ of winery wastewater containing $1349 \pm 25.24 \mathrm{mg} / \mathrm{L}$ of TOC using an open cell with constant agitation. In order to study the effect of the anode material on the degradation of the organic pollutants present in the wastewater, three electrodes were used in different experiments, namely $\mathrm{MMO}-\mathrm{Cl}_{2}$, $\mathrm{MMO}-\mathrm{O}_{2}$, and BDD. All the tests were carried out at room temperature, with an initial $\mathrm{pH}$ of $4.28 \pm 0.16$, without the addition of electrolyte support and applying a current density of $30 \mathrm{~mA} / \mathrm{cm}^{2}$. Each electrolysis took $540 \mathrm{~min}$ (min.).

Figure 3 shows that when MMO electrodes were used as anodes, only a degradation of organic matter of $1.70 \%$ and $3.34 \%$ was achieved for $\mathrm{MMO}-\mathrm{Cl}_{2}$ and $\mathrm{MMO}-\mathrm{O}_{2}$, respectively. Similar results were obtained by Ribeiro, et al. [35]. The researchers used the $\mathrm{MMO}-\mathrm{Cl}_{2}$ and $\mathrm{MMO}-\mathrm{O}_{2}$ electrodes as anodes to study the electrochemical degradation of $50 \mathrm{mg} / \mathrm{L}$ of the Ponceau $2 \mathrm{R}$ dye with $\mathrm{NaClO}_{4}$ as a supporting electrolyte at different values of current density and at room temperature. The results obtained showed that organic matter fails to be removed when applying $25 \mathrm{~mA} / \mathrm{cm}^{2}$. Furthermore, it is only possible to reduce TOC up to $7 \%$ and $11 \%$ in the case of the $\mathrm{MMO}-\mathrm{O}_{2}$ and $\mathrm{MMO}-\mathrm{Cl}_{2}$ anodes, respectively, when $200 \mathrm{~mA} / \mathrm{cm}^{2}$ is applied. This poor decrease in TOC was attributed to the formation of intermediates and the catalytic effect on the oxygen evolution reaction, which leads to the lower efficiency of these electrodes.

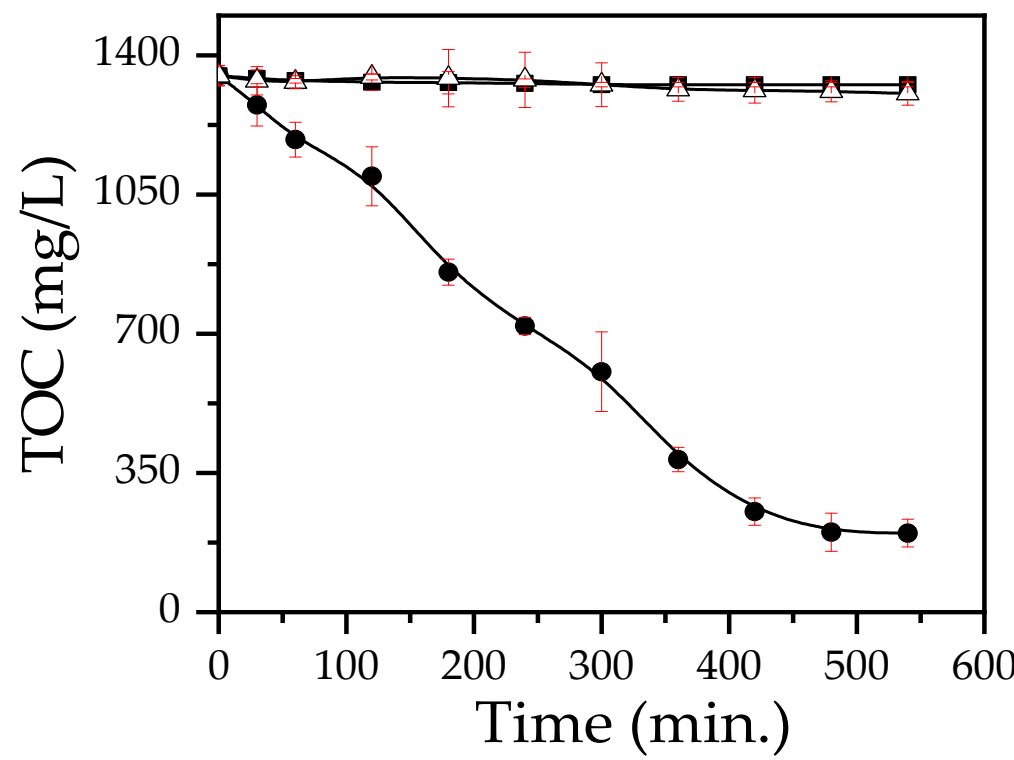

Figure 3. Mineralization by TOC decay of winery wastewater during electrolysis without the addition

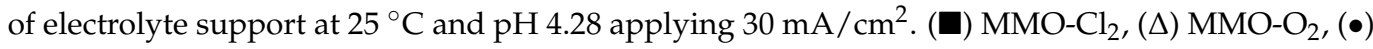
BDD. Samples tested: 11 . 
Conversely, when working with the BDD electrode, $85 \%$ of the organic matter is removed without the addition of a supporting electrolyte. This may be because, since BDD is a non-active anode, the weak interaction of BDD - ${ }^{\bullet} \mathrm{OH}$, together with its high overpotential for oxygen evolution, generates higher amounts of reactive physisorbed $\mathrm{BDD}\left({ }^{\bullet} \mathrm{OH}\right)$ radicals that mineralize more effectively the contaminants present in the water $[22,34]$. Another key factor in this result may also be the formation of active chlorine species $\left(\mathrm{Cl}_{2}, \mathrm{HClO}, \mathrm{ClO}^{-}\right)$that can oxidize organic contaminants $[15,24]$. These species can be generated from the direct oxidation of the chloride ion on the anode surface to soluble chlorine $\left(\mathrm{Cl}_{2 \mathrm{aq}}\right)$ (reaction (5)) [14,24,32]. According to Brillas and Martínez-Huitle [15], if the local concentration of dissolved chlorine exceeds its solubility, supersaturation propels the generation of bubbles of chlorine gas. The electrogenerated $\mathrm{Cl}_{2}$ can react with the chloride ion to form the trichloride ion (reaction (6)) or can be hydrolyzed to allow for the formation of hypochlorous acid $(\mathrm{HClO})$ (reaction $(7))$, being in equilibrium with the hypochlorite ion $\left(\mathrm{ClO}^{-}\right)$in the bulk solution (reaction (8)).

$$
\begin{gathered}
2 \mathrm{Cl}^{-} \rightarrow \mathrm{Cl}_{2(\mathrm{aq})}+2 \mathrm{e}^{-} \\
\mathrm{Cl}_{2(\mathrm{aq})}+\mathrm{Cl}^{-} \rightleftharpoons \mathrm{Cl}_{3}{ }^{-} \\
\mathrm{Cl}_{2(\mathrm{aq})}+\mathrm{H}_{2} \mathrm{O} \rightleftharpoons \mathrm{HClO}+\mathrm{H}^{+}+\mathrm{Cl}^{-} \\
\mathrm{HClO} \rightleftharpoons \mathrm{ClO}^{-}+\mathrm{H}^{+}
\end{gathered}
$$

Figure 4 a shows the variation of maximum absorbance over time, which was measured at $254 \mathrm{~nm}$. The absorbance decay of the solution is dependent on the anode material used. In addition, absorbance decay reaches $60 \%$ and $65 \%$ with the $\mathrm{MMO}-\mathrm{Cl}_{2}$ and $\mathrm{MMO}-$ $\mathrm{O}_{2}$ electrodes, respectively. This indicates a decrease in compounds that absorb at that wavelength, for example, polyphenols. In the case of BDD, an increase in maximum absorbance is observed during the first $180 \mathrm{~min}$. This increase could have been caused by the formation of reaction intermediates. However, at the end of the process, an $85 \%$ decrease in absorbance is observed. This is a result of the higher generation of ${ }^{\bullet} \mathrm{OH}$ when using a BDD electrode, which attacks the contaminants in the solution, causing a more pronounced decay than MMO electrodes. A similar trend to that obtained in this work when the BDD electrode is used was reported by Collivignarelli, et al. [48] in a study on the discoloration of a real effluent from the pharmaceutical industry.

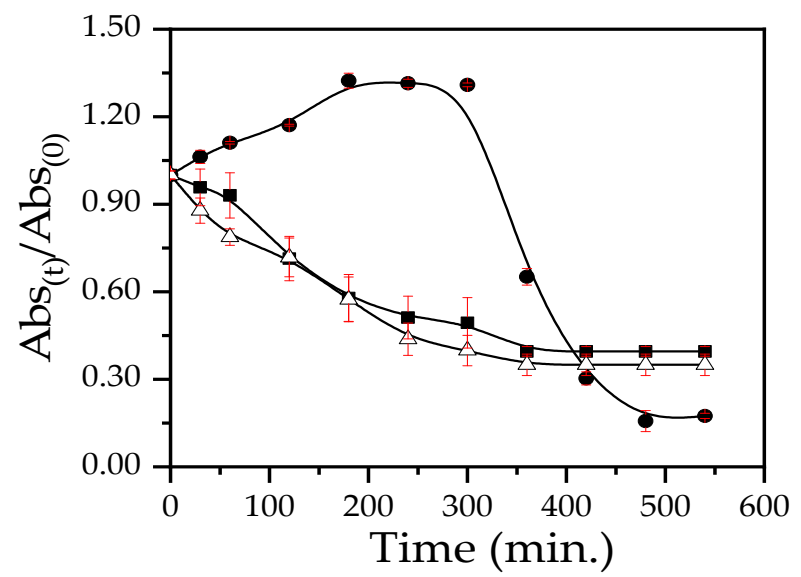

(a)

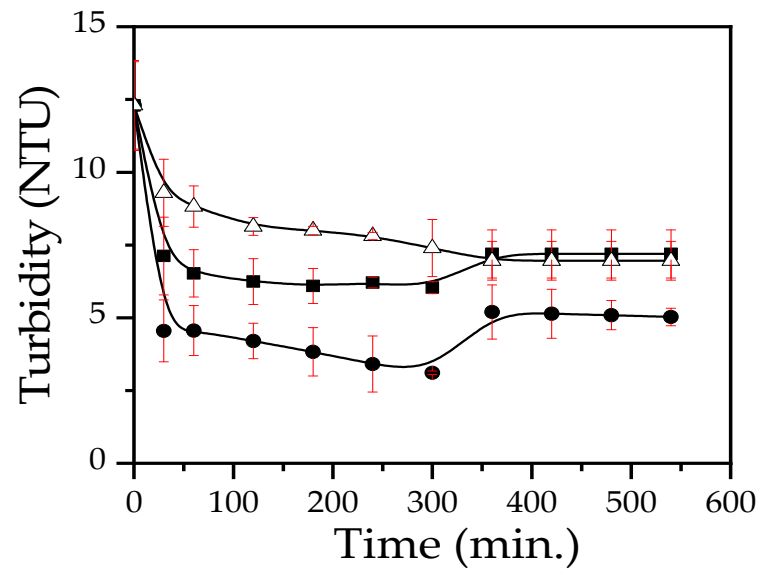

(b)

Figure 4. (a) Evolution of normalized absorbance at $254 \mathrm{~nm}$ and (b) turbidity decay of winery wastewater during electrolysis without the addition of electrolyte support at $25{ }^{\circ} \mathrm{C}$ and $\mathrm{pH} 4.28$

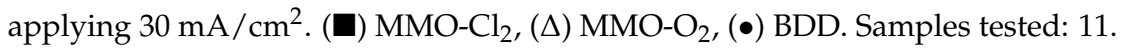


Figure $4 b$ shows a decrease in turbidity in all three cases. However, statistically significant differences were found in experiments using BDD as an anode compared to experiments employing MMO (value; $p<0.05$ ). In this sense, values are better for BDD, in whose case turbidity is reduced to 5.03 NTU. This result agrees with that reported by Candia-Onfray, et al. [14], who only achieved complete elimination of turbidity when using a current density of $60 \mathrm{~mA} / \mathrm{cm}^{2}$. This indicates that increasing the density current promotes the hydrolysis of solids, which is possibly due to an increase in the amount of ${ }^{\bullet} \mathrm{OH}$ generated. At this point, it is important to mention that when working with a higher density current, higher energy expenditure can occur; therefore, in this study, it was decided to work with $30 \mathrm{~mA} / \mathrm{cm}^{2}$ to maintain a balance between both factors.

Figure 5a shows the behavior of $\mathrm{pH}$ over time for each electrolysis. An increase in $\mathrm{pH}$ is expected in all cases due to the possible decrease in the concentration of protons in the medium as a result of the reduction of these on the stainless-steel cathode to produce $\mathrm{H}_{2}$. In this context, when $\mathrm{MMO}$ anodes were used, a small increase in $\mathrm{pH}$ was observed, being $4.45 \pm 0.16$ and $4.36 \pm 0.13$ the final $\mathrm{pH}$ when working with $\mathrm{MMO}-\mathrm{Cl}_{2}$ and $\mathrm{MMO}-\mathrm{O}_{2}$, respectively. No statistically significant differences were found between experiments with MMO as anode (value- $p>0.05$ ). However, in the case of BDD, $\mathrm{pH}$ increased to $8.15 \pm 0.10$. In this case, statistically significant differences were found in the experiments with BDD as an anode compared to the experiments with MMO (value- $p<0.05$ ). This may be related to the electrocatalytic effect on the evolution of chloride and the active chlorine species present in wastewater, i.e., BDD forms more ${ }^{\bullet} \mathrm{OH}$ than the $\mathrm{MMO}$ electrodes, as it has a higher overpotential for oxygen evolution. These radicals react with the chlorides present in the medium and form chlorine oxides and active chlorine species, which increase $\mathrm{pH}$. This result promotes a further expansion of wastewater treatment technologies because it would not be necessary to add any chemical compound to adjust $\mathrm{pH}$.

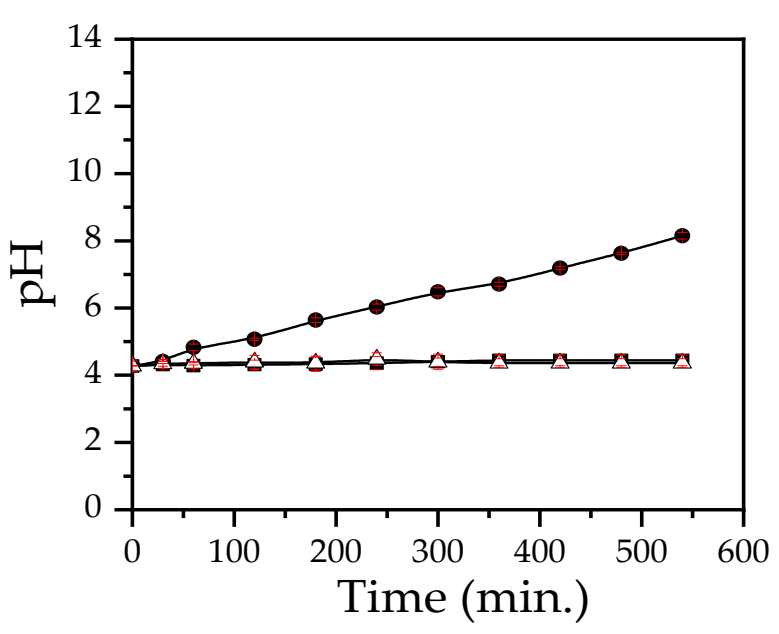

(a)

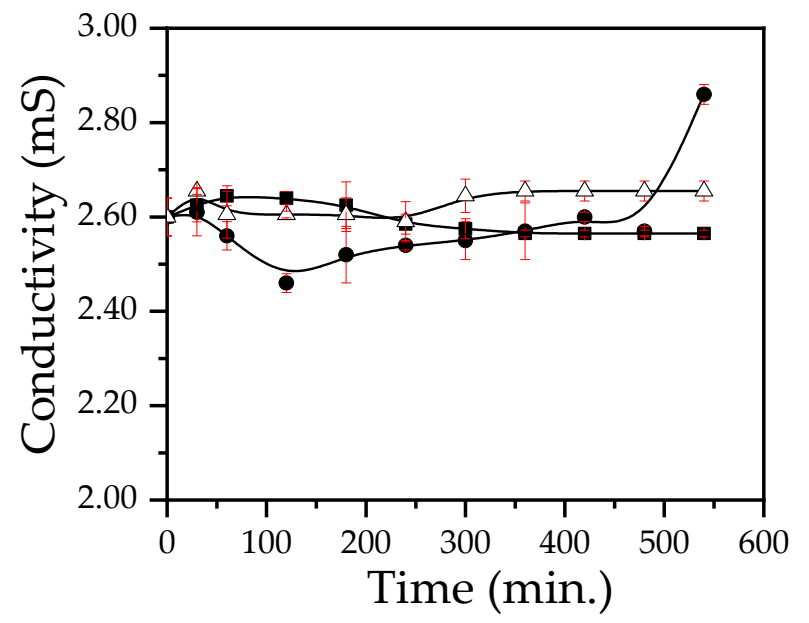

(b)

Figure 5. (a) Evolution of $\mathrm{pH}$ and (b) conductivity of winery wastewater during electrolysis without the addition of electrolyte support at $25^{\circ} \mathrm{C}$ and $\mathrm{pH} 4.28$ applying $30 \mathrm{~mA} / \mathrm{cm}^{2}$. MMO-O ${ }_{2},(\bullet)$ BDD. Samples tested: 11 .

The variation in conductivity over time is shown in Figure 5b. In general, there was no significant changes in this parameter in any of the three cases. The lowest conductivity occurred when the BDD electrode was used; however, after two hours, conductivity increases until $2.86 \pm 0.02 \mathrm{mS}$. In the case of the MMO electrodes, statistically significant differences were found (value- $p>0.05$ ). Conductivity varied between $2.60 \pm 0.04$ and $2.57 \pm 0.01 \mathrm{mS}\left(\mathrm{MMO}^{\left.-\mathrm{Cl}_{2}\right)}\right.$ and $2.60 \pm 0.04$ and $2.66 \pm 0.02\left(\mathrm{MMO}-\mathrm{O}_{2}\right)$. These variations in conductivity are associated with the variation of the ions in the medium (as discussed in Section 3.3). 


\subsection{Evolution of Carboxylic Acids and Ions during Electrolysis}

Figure 6 shows the changes in the concentration of carboxylic acids during electrolysis. Ion exclusion chromatography reveals the presence of oxamic $\left(\mathrm{r}_{\mathrm{t}}=8.53 \mathrm{~min}\right)$, acetic $\left(\mathrm{r}_{\mathrm{t}}=14.31 \mathrm{~min}\right)$, and propionic acid $\left(\mathrm{r}_{\mathrm{t}}=17.65 \mathrm{~min}\right)$ in the electrolyzed samples. Oxamic acid is often one of the main intermediates of the degradation of $\mathrm{N}$-aromatics by EAOPs [19,49]. Furthermore, it is one of the ultimate carboxylic acids, since it is directly oxidized to $\mathrm{CO}_{2}[21,50,51]$. Figure 6 shows that the oxamic acid concentration did not exceed $4.59 \mathrm{mg} / \mathrm{L}$, being rapidly degraded when using MMO electrodes (Figure 6a,b). In this case, there are no statistically significant differences between the experiments where these electrodes are used as anodes (value- $p>0.05$ ). However, statistically significant differences were found in the experiments with BDD as an anode compared to the experiments with MMO (value- $p<0.05)$.

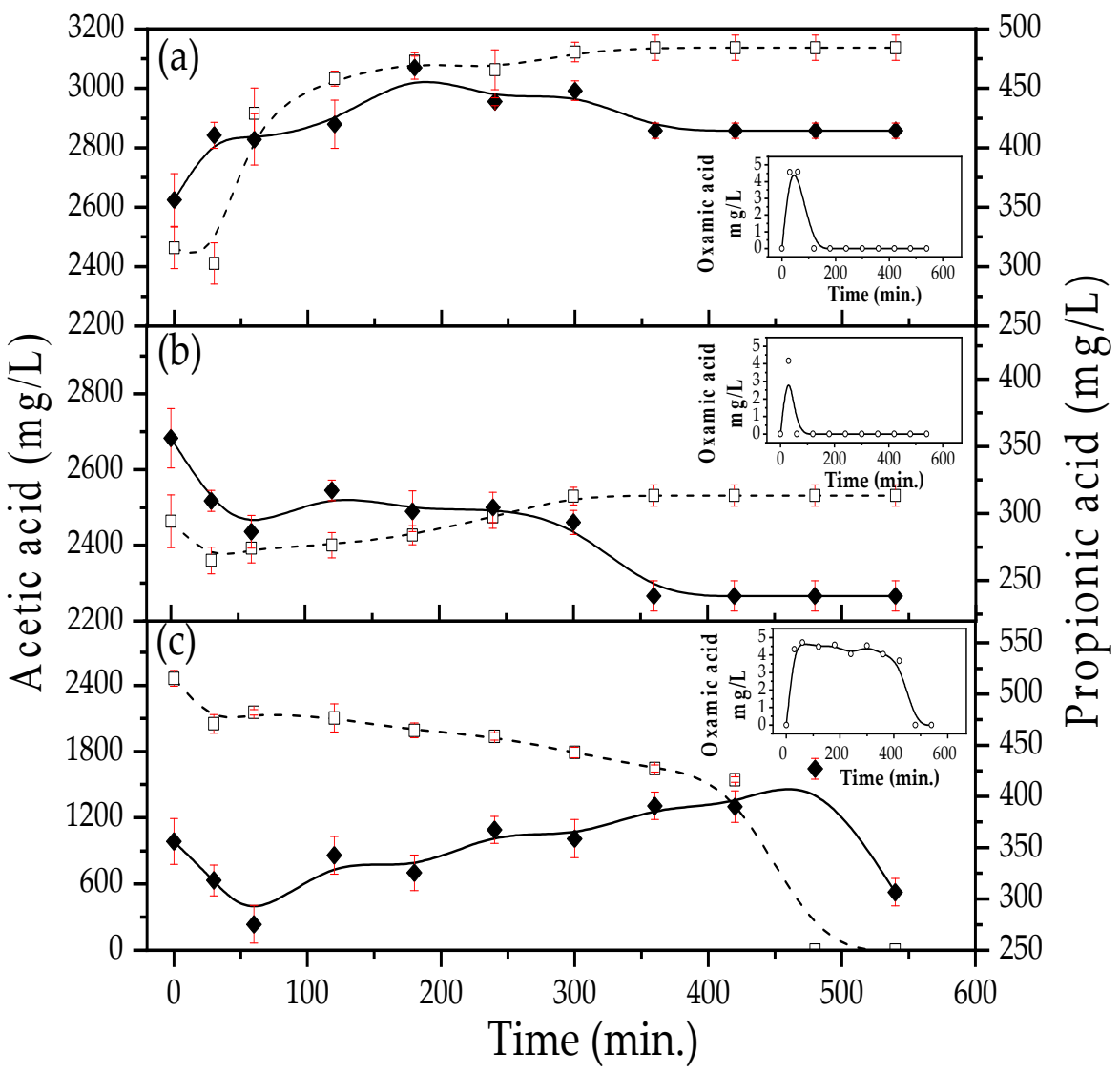

Figure 6. Evolution of carboxylic acid during electrolysis without the addition of electrolyte support

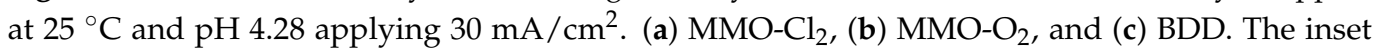
panels present the expansion of oxamic acid during each electrolysis: $(\bigcirc)$ Oxamic, $(\square)$ Acetic, $(\diamond)$ Propionic acids. Samples tested: 11 .

Acetic acid is characteristic of winery wastewater [12,40]. Figure $6 \mathrm{c}$ shows that acetic acid is removed after 480 min only when using BDD as an anode. Conversely, with the $\mathrm{MMO}-\mathrm{Cl}_{2}$ and $\mathrm{MMO}-\mathrm{O}_{2}$ electrodes, the concentration of acetic acid increased by $27 \%$ and $3 \%$, respectively (Figure $6 \mathrm{a}, \mathrm{b}$ ). Regarding the concentration of propionic acid, a variation was found between $239 \pm 11.24$ and $448 \pm 8.36 \mathrm{mg} / \mathrm{L}$. When using the BDD and MMO- $\mathrm{O}_{2}$ electrodes, a mineralization percentage of $14 \%$ and $33 \%$ is obtained, respectively (Figure $6 \mathrm{~b}, \mathrm{c}$ ). However, when using $\mathrm{MMO}-\mathrm{Cl}_{2}$, the concentration of propionic acid increased by $16 \%$ (Figure 6a). It should be noted that propionic acid is also part of the composition of winery wastewater [52]; however, this can be generated as an intermediate product of the action of ${ }^{\bullet} \mathrm{OH}$. 
Both in the measurement of acetic and propionic acid, statistically significant differences were found in all experiments. The low mineralization of organic matter when working with MMO electrodes may be related to the presence of these acids that could not be mineralized.

Another important factor to consider in the mineralization process is the change in the concentration of inorganic ions. Figure 7 shows the variation of the concentration of the six ions detected by ion chromatography: chloride $\left(\mathrm{Cl}^{-}\right)$, chlorate $\left(\mathrm{ClO}_{3}{ }^{-}\right)$, hypochlorite $\left(\mathrm{ClO}^{-}\right)$, nitrate $\left(\mathrm{NO}_{3}{ }^{-}\right)$, phosphate $\left(\mathrm{PO}_{4}{ }^{3-}\right)$, and sulfate $\left(\mathrm{SO}_{4}{ }^{2-}\right)$.

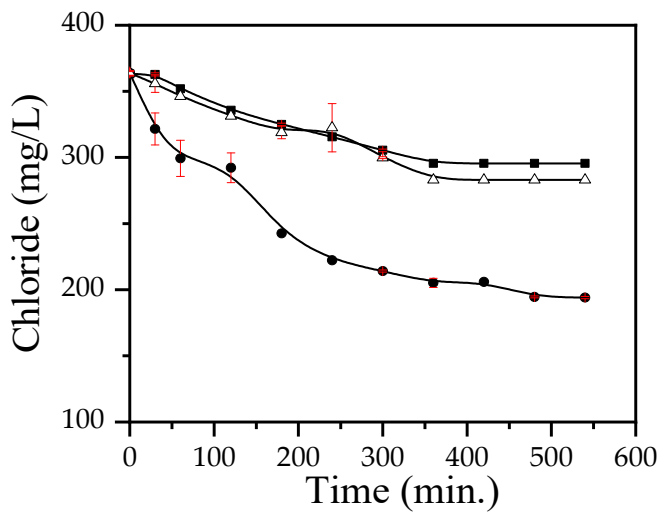

(a)

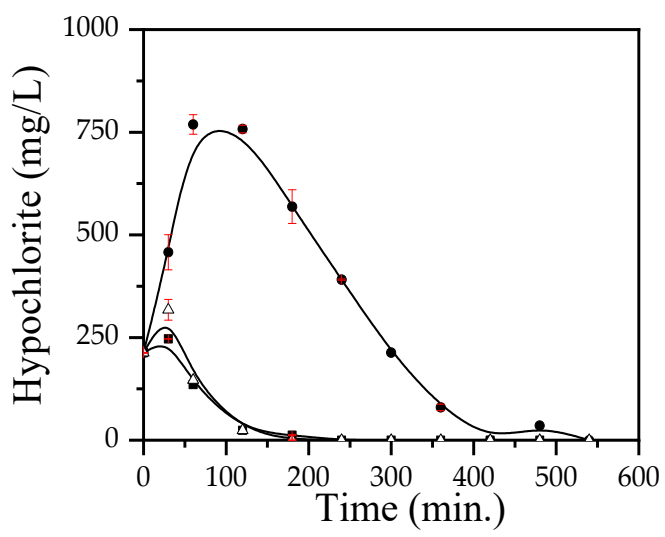

(c)

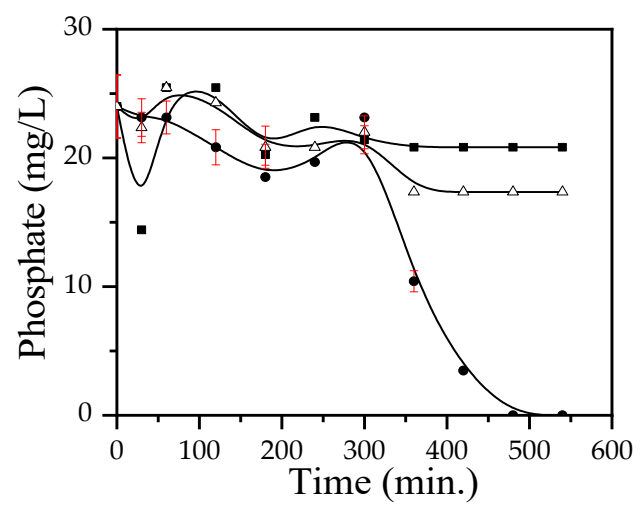

(e)

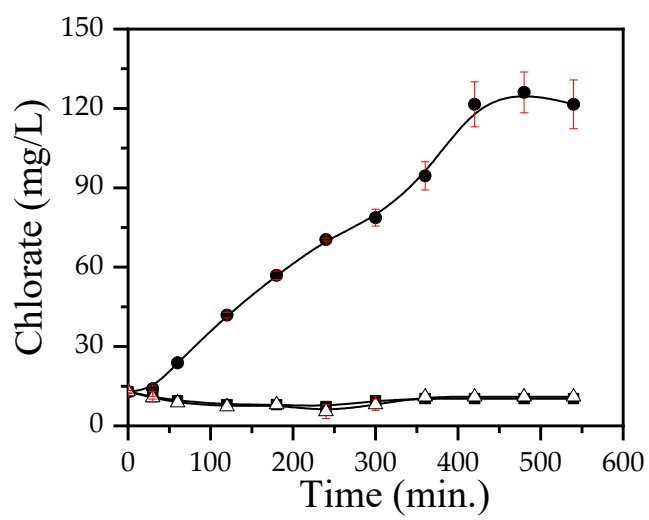

(b)

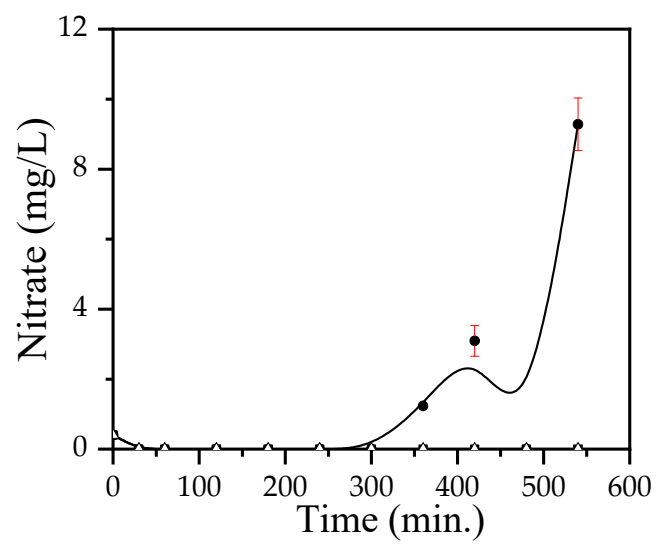

(d)

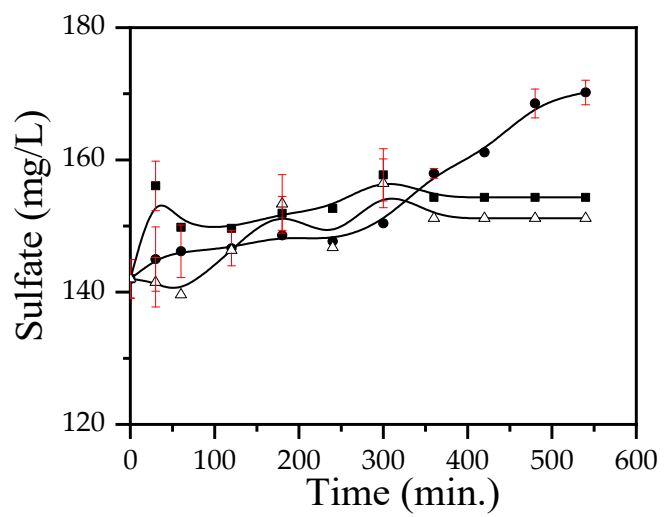

(f)

Figure 7. Monitoring of ion concentration during each electrolysis without the addition of electrolyte support at $25^{\circ} \mathrm{C}$ and $\mathrm{pH} 4.28$ applying $30 \mathrm{~mA} / \mathrm{cm}^{2}$. (a) Chloride, (b) Chlorate, (c) Hypochlorite,

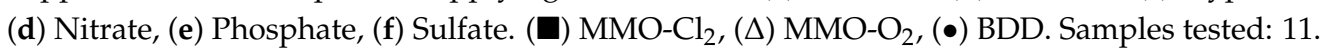


The concentration of the $\mathrm{Cl}^{-}$ion decreased over time (Figure 7a), specifically from $364 \pm 1.73 \mathrm{mg} / \mathrm{L}$ to $295 \pm 0.51,194 \pm 0.85$, and $283 \pm 0.68 \mathrm{mg} / \mathrm{L}$ when using $\mathrm{MMO}-\mathrm{Cl}_{2}$, $\mathrm{BDD}$, and $\mathrm{MMO}-\mathrm{O}_{2}$, respectively. This decrease is due to the continuous oxidation of the $\mathrm{Cl}^{-}$ion on the anode, which produces active chlorine species [53].

Figure $7 \mathrm{~b}$ shows that after $540 \mathrm{~min}$, there is an increase of approximately 9.40 times in $\mathrm{ClO}_{3}{ }^{-}$ion concentration when the BDD electrode is used. In the case of the MMO electrodes, the generation of $\mathrm{ClO}_{3}{ }^{-}$ion was low, which is revealed by the low decrease in $\mathrm{Cl}^{-}$.

The $\mathrm{ClO}_{3}{ }^{-}$ion can be formed by the chemical reaction between the $\mathrm{ClO}^{-}$ion and the hypochlorous acid $(\mathrm{HClO})$ (reaction (9)) or by direct oxidation of the $\mathrm{ClO}^{-}$ion on the electrode without the action of the hydroxyl radicals $\left({ }^{\bullet} \mathrm{OH}\right)$ (reaction (10)).

$$
\begin{gathered}
\mathrm{ClO}^{-}+2 \mathrm{HClO} \rightarrow \mathrm{ClO}_{3}^{-}+2 \mathrm{Cl}^{-}+2 \mathrm{H}^{+} \\
6 \mathrm{ClO}^{-}+3 \mathrm{H}_{2} \mathrm{O} \rightarrow 2 \mathrm{ClO}_{3}^{-}+4 \mathrm{Cl}^{-}+6 \mathrm{H}^{+}+3 / 2 \mathrm{O}_{2}+6 \mathrm{e}^{-}
\end{gathered}
$$

It is noteworthy that in this work, chlorite $\left(\mathrm{ClO}_{2}{ }^{-}\right)$was not observed in any case. According to Espinoza, et al. [19], this may be because $\mathrm{ClO}_{2}{ }^{-}$is an intermediate in the formation of $\mathrm{ClO}_{3}{ }^{-}$(reaction (11)) and therefore can be consumed quickly.

$$
\mathrm{ClO}_{2}{ }^{-}+{ }^{\bullet} \mathrm{OH} \rightarrow \mathrm{ClO}_{3}{ }^{-}+\mathrm{H}^{+}+\mathrm{e}^{-}
$$

Concerning the $\mathrm{ClO}^{-}$ion, in Figure $7 \mathrm{c}$, when working with the BDD electrode, $\mathrm{ClO}^{-}$ concentration reached its maximum value at $60 \mathrm{~min}(769 \pm 23.70 \mathrm{mg} / \mathrm{L})$, which later decreased to $36 \pm 0.13 \mathrm{mg} / \mathrm{L}$ at $480 \mathrm{~min}$. In the case of MMO electrodes, the maximum concentration of the $\mathrm{ClO}^{-}$ion was obtained at $30 \mathrm{~min}$, being $247 \pm 0.24 \mathrm{mg} / \mathrm{L}$ and $318 \pm 25.14 \mathrm{mg} / \mathrm{L}$ for $\mathrm{MMO}-\mathrm{Cl}_{2}$ and $\mathrm{MMO}-\mathrm{O}_{2}$, respectively. This ion completely disappeared at 240 min when working with the MMO electrodes; however, when the BDD electrode was used, $\mathrm{ClO}^{-}$disappeared at the end of electrolysis (540 $\mathrm{min}$ ). This result indicates that when a BDD electrode is used, because more ${ }^{\bullet} \mathrm{OH}$ is formed than in $\mathrm{MMO}$ electrodes, ${ }^{\bullet} \mathrm{OH}$ can react with the chlorides present in the water, producing a greater quantity of active chlorine species such as $\mathrm{ClO}^{-}$, as shown in reaction (12). Reaction (8) shows another way of obtaining $\mathrm{ClO}^{-}$ion.

$$
\mathrm{Cl}^{-}+{ }^{\bullet} \mathrm{OH} \rightarrow \mathrm{ClO}^{-}+\mathrm{H}^{+}+\mathrm{e}^{-}
$$

It should be noted that since the final concentration of the chlorine species is lower than the initial concentration of $\mathrm{Cl}^{-}$, there could be a risk that halogenated organic compounds have been formed [54], which could explain the low mineralization of organic matter when MMO electrodes are used.

Regarding $\mathrm{NO}_{3}{ }^{-}$ions (Figure $7 \mathrm{~d}$ ), they totally disappeared after 30 min when working with the MMO electrodes, whereas an increase of 23 times was observed with the BDD electrode compared to the initial value at $540 \mathrm{~min}$, which is associated with the decomposition of organic compounds that present atoms of nitrogen [40]. Nevertheless, this value $(9.28 \mathrm{mg} / \mathrm{L})$ is within the values accepted by Chilean regulations. No other nitrogenated ions such as ammonium $\left(\mathrm{NH}_{4}{ }^{+}\right)$or nitrite $\left(\mathrm{NO}_{2}{ }^{-}\right)$were detected.

In Figure 7e, the $\mathrm{PO}_{4}{ }^{3-}$ ions decreased in all three cases. When working with the MMO electrodes, decreases of $17 \%$ and $29 \%$ were obtained for $\mathrm{MMO}-\mathrm{Cl}_{2}$ and $\mathrm{MMO}-\mathrm{O}_{2}$, respectively. In the case of the $\mathrm{BDD}$ electrode, the $\mathrm{PO}_{4}{ }^{3-}$ ion disappears after $480 \mathrm{~min}$. According to [54], this decrease can be attributed to scaling in the electrolysis cell.

The concentration of $\mathrm{SO}_{4}{ }^{2-}$ ions increased by $8 \%$ and $6 \%$ when working with MMO$\mathrm{Cl}_{2}$ and $\mathrm{MMO}-\mathrm{O}_{2}$, respectively (Figure $7 \mathrm{f}$ ). In the case of $\mathrm{BDD}$, the sulfate ion concentration increased by $20 \%$ at the end of electrolysis (540 $\mathrm{min}$ ) compared to the initial value. This increase can be attributed to the degradation of organic compounds containing sulfur atoms $[24,40,54]$. 
It is noteworthy that depending on the salts dissolved in the wastewater, other oxidants can be produced that, despite having a lower oxidation power than ${ }^{\bullet} \mathrm{OH}$, can also improve the oxidation power of the system. Among these oxidants that are formed in the solution when current is applied are $\mathrm{P}_{2} \mathrm{O}_{8}{ }^{4-}$ and $\mathrm{S}_{2} \mathrm{O}_{8}{ }^{2-}$. The formation of these oxidants occurs when ${ }^{\bullet} \mathrm{OH}$ reacts with the phosphate and sulfate salt dissolved on the anode surface [18], with the subsequent formation of radical species (reactions 13 and 14) that are then combined as shown in reactions 15 and 16.

$$
\begin{gathered}
\mathrm{PO}_{4}{ }^{3-}+{ }^{\bullet} \mathrm{OH} \rightarrow\left(\mathrm{PO}_{4}{ }^{2-}\right)^{\bullet}+\mathrm{e}^{-} \\
\mathrm{SO}_{4}{ }^{2-}+{ }^{\bullet} \mathrm{OH} \rightarrow\left(\mathrm{SO}_{4}{ }^{-}\right)^{\bullet}+\mathrm{e}^{-} \\
\left(\mathrm{PO}_{4}{ }^{2-}\right)^{\bullet}+\left(\mathrm{PO}_{4}{ }^{2-}\right)^{\bullet} \rightarrow \mathrm{P}_{2} \mathrm{O}_{8}{ }^{4-} \\
\left(\mathrm{SO}_{4-}\right)^{\bullet}+\left(\mathrm{SO}_{4-}\right)^{\bullet} \rightarrow \mathrm{S}_{2} \mathrm{O}_{8}{ }^{2-}
\end{gathered}
$$

These results demonstrate the importance of inorganic ions in the formation of different species that can improve the oxidative power of the system.

\section{Conclusions}

The monitoring of different parameters in the winery wastewater of a Chilean industry confirmed the presence of a high content of easily biodegradable organic matter and great seasonality. This work demonstrated that the effectiveness of the anodic oxidation process is directly related to the type of anodic material used. In this sense, only with the use of a BDD anode, $85 \%$ of the organic matter present in the winery wastewater was removed without the need of modifying the initial characteristics of the sample or adding a support electrolyte. In addition, using the BDD anode, the highest percentage of decrease in absorbance and turbidity was achieved, which were $85 \%$ and 59\%, respectively. These results demonstrate the greater oxidative power exhibited by the BDD anode by forming more hydroxyl radicals than the MMO electrodes. The presence of carboxylic acids such as acetic and propionic acid was found, which could not be removed when working with the MMO electrodes. The monitoring of ions during electrolysis demonstrated the importance of inorganic ions already in the water to the formation of different species that can improve the oxidative power of the system. These results may contribute to the future implementation of the technology at an industrial level.

Author Contributions: Conceptualization, Y.L. and R.S.; methodology, L.C.E. and R.S.; validation, Y.L., R.S. and C.H.; formal analysis, Y.L. and R.S.; investigation, Y.L.; resources, R.S., C.H. and V.G.; data curation, Y.L. and R.S.; writing—original draft preparation, Y.L.; writing-review and editing, R.S., C.H., L.C.E. and V.G.; visualization, R.S.; supervision, R.S.; project administration, R.S. and C.H.; funding acquisition, R.S. All authors have read and agreed to the published version of the manuscript.

Funding: This research was funded by Associative DICYT project 021811HC_DAS and ANID/ FONDAP/15110019 SERC Chile.

Institutional Review Board Statement: Not applicable.

Informed Consent Statement: Not applicable.

Data Availability Statement: Data are available on-demand from the corresponding author.

Acknowledgments: We are grateful to 5392102SG-ACDicyt-USACH and to the National Agency for Research and Development (ANID)/Scholarship Program/National Doctorate/2017-21170083 awarded to Yeney Lauzurique Guerra.

Conflicts of Interest: The authors declare no conflict of interest. 


\section{References}

1. Flores, L.; Garcia, J.; Pena, R.; Garfi, M. Constructed wetlands for winery wastewater treatment: A comparative Life Cycle Assessment. Sci. Total Environ. 2019, 659, 1567-1576. [CrossRef]

2. Montalvo, S.; Martinez, J.; Castillo, A.; Huiliñir, C.; Borja, R.; García, V.; Salazar, R. Sustainable energy for a winery through biogas production and its utilization: A Chilean case study. Sustain. Energy Technol. 2020, 37, 100640. [CrossRef]

3. Vital-Jacome, M.; Cazares-Granillo, M.; Carrillo-Reyes, J.; Buitron, G. Characterization and anaerobic digestion of highly concentrated Mexican wine by-products and effluents. Water Sci. Technol. 2020, 81, 190-198. [CrossRef]

4. Basset, N.; Santos, E.; Dosta, J.; Mata-Álvarez, J. Start-up and operation of an AnMBR for winery wastewater treatment. Ecol. Eng. 2016, 86, 279-289. [CrossRef]

5. Valderrama, C.; Ribera, G.; Bahí, N.; Rovira, M.; Giménez, T.; Nomen, R.; Lluch, S.; Yuste, M.; Martinez-Lladó, X. Winery wastewater treatment for water reuse purpose: Conventional activated sludge versus membrane bioreactor (MBR): A comparative case study. Desalination 2012, 306, 1-7. [CrossRef]

6. Policastro, G.; Luongo, V.; Fabbricino, M. Biohydrogen and poly- $\beta$-hydroxybutyrate production by winery wastewater photofermentation: Effect of substrate concentration and nitrogen source. J. Environ. Manag. 2020, 271, 111006. [CrossRef]

7. Ioannou, L.; Fatta-Kassinos, D. Solar photo-Fenton oxidation against the bioresistant fractions of winery wastewater. J. Environ. Chem. Eng. 2013, 1, 703-712. [CrossRef]

8. Díez, A.; Iglesias, O.; Rosales, E.; Sanromán, M.; Pazos, M. Optimization of two-chamber photo electro Fenton reactor for the treatment of winery wastewater. Process Saf. Environ. 2016, 101, 72-79. [CrossRef]

9. Amor, C.; Rodríguez-Chueca, J.; Fernandes, J.L.; Domínguez, J.R.; Lucas, M.S.; Peres, J.A. Winery wastewater treatment by sulphate radical based-advanced oxidation processes (SR-AOP): Thermally vs UV-assisted persulphate activation. Process Saf. Environ. 2019, 122, 94-101. [CrossRef]

10. Lauzurique, Y.; Fermoso, F.G.; Sánchez, N.; Castillo, A.; Valdés, N.; Tello, M.; Salazar, R.; García, V.; Huiliñir, C. Effect of the addition of fly ash on the specific methane production and microbial communities in the anaerobic digestion of real winery wastewater. J. Chem. Technol. Biotechnol. 2021, 96, 2882-2890. [CrossRef]

11. Domínguez, C.M.; Quintanilla, A.; Casas, J.A.; Rodriguez, J.J. Treatment of real winery wastewater by wet oxidation at mild temperature. Sep. Purif. Technol. 2014, 129, 121-128. [CrossRef]

12. Ioannou, L.; Michael, C.; Kyriakou, S.; Fatta-Kassinos, D. Solar Fenton: From pilot to industrial scale application for polishing winery wastewater pretreated by MBR. J. Chem. Technol. Biotechnol. 2014, 89, 1067-1076. [CrossRef]

13. Lucas, M.S.; Peres, J.A.; Puma, G.L. Treatment of winery wastewater by ozone-based advanced oxidation processes $\left(\mathrm{O}_{3}, \mathrm{O}_{3} / \mathrm{UV}\right.$ and $\mathrm{O}_{3} / \mathrm{UV} / \mathrm{H}_{2} \mathrm{O}_{2}$ ) in a pilot-scale bubble column reactor and process economics. Sep. Purif. Technol. 2010, 72, 235-241. [CrossRef]

14. Candia-Onfray, C.; Espinoza, N.; Sabino da Silva, E.B.; Toledo-Neira, C.; Espinoza, L.C.; Santander, R.; García, V.; Salazar, R. Treatment of winery wastewater by anodic oxidation using BDD electrode. Chemosphere 2018, 206, 709-717. [CrossRef]

15. Brillas, E.; Martínez-Huitle, C.A. Decontamination of wastewaters containing synthetic organic dyes by electrochemical methods. An updated review. Appl. Catal. B Environ. 2015, 166, 603-643. [CrossRef]

16. Espinoza, C.; Romero, J.; Villegas, L.; Cornejo-Ponce, L.; Salazar, R. Mineralization of the textile dye acid yellow 42 by solar photoelectro-Fenton in a lab-pilot plant. J. Hazard. Mater. 2016, 319, 24-33. [CrossRef]

17. Nidheesh, P.; Zhou, M.; Oturan, M.A. An overview on the removal of synthetic dyes from water by electrochemical advanced oxidation processes. Chemosphere 2018, 197, 210-227. [CrossRef] [PubMed]

18. Sirés, I.; Brillas, E.; Oturan, M.A.; Rodrigo, M.A.; Panizza, M. Electrochemical advanced oxidation processes: Today and tomorrow. A review. Environ. Sci. Pollut. Res. 2014, 21, 8336-8367. [CrossRef] [PubMed]

19. Espinoza, L.C.; Sepúlveda, P.; García, A.; de Godoi, D.M.; Salazar, R. Degradation of oxamic acid using dimensionally stable anodes (DSA) based on a mixture of $\mathrm{RuO}_{2}$ and $\mathrm{IrO}_{2}$ nanoparticles. Chemosphere 2020, 251, 126674. [CrossRef]

20. Duarte, J.L.; Meili, L.; Gomes, L.M.; Melo, J.M.; Ferro, A.B.; Tavares, M.G.; Tonholo, J.; Zanta, C.L. Electrochemical degradation of 17- $\alpha$-Methyltestosterone over DSA ${ }^{\circledR}$ electrodes. Chem. Eng. Process 2019, 142, 107548. [CrossRef]

21. Salazar, R.; Ureta-Zañartu, M.S.; González-Vargas, C.; do Nascimento Brito, C.; Martinez-Huitle, C.A. Electrochemical degradation of industrial textile dye disperse yellow 3: Role of electrocatalytic material and experimental conditions on the catalytic production of oxidants and oxidation pathway. Chemosphere 2018, 198, 21-29. [CrossRef] [PubMed]

22. Garcia-Segura, S.; Keller, J.; Brillas, E.; Radjenovic, J. Removal of organic contaminants from secondary effluent by anodic oxidation with a boron-doped diamond anode as tertiary treatment. J. Hazard. Mater. 2015, 283, 551-557. [CrossRef] [PubMed]

23. Rocha, J.H.B.; Solano, A.M.S.; Fernandes, N.S.; da Silva, D.R.; Peralta-Hernandez, J.M.; Martínez-Huitle, C.A. Electrochemical degradation of remazol red BR and novacron blue CD dyes using diamond electrode. Electrocatalysis 2012, 3, 1-12. [CrossRef]

24. Calzadilla, W.; Espinoza, L.C.; Diaz-Cruz, M.S.; Sunyer, A.; Aranda, M.; Peña-Farfal, C.; Salazar, R. Simultaneous degradation of 30 pharmaceuticals by anodic oxidation: Main intermediaries and by-products. Chemosphere 2020, 269, 128753. [CrossRef]

25. Espinoza, L.C.; Candia-Onfray, C.; Vidal, J.; Salazar, R. Influence of the chemical nature of Boron-Doped diamond anodes on wastewater treatments. Curr. Opin. Solid State Mater. Sci. 2021, 25, 100963. [CrossRef]

26. Markou, V.; Kontogianni, M.-C.; Frontistis, Z.; Tekerlekopoulou, A.G.; Katsaounis, A.; Vayenas, D. Electrochemical treatment of biologically pre-treated dairy wastewater using dimensionally stable anodes. J. Environ. Manag. 2017, 202, 217-224. [CrossRef]

27. Comninellis, C.; Chen, G. Electrochemistry for the Environment; Springer: New York, NY, USA, 2010. 
28. Martínez-Pachón, D.; Ibáñez, M.; Hernández, F.; Torres-Palma, R.A.; Moncayo-Lasso, A. Photo-electro-Fenton process applied to the degradation of valsartan: Effect of parameters, identification of degradation routes and mineralization in combination with a biological system. J. Environ. Chem. Eng. 2018, 6, 7302-7311. [CrossRef]

29. Coria, G.; Sirés, I.; Brillas, E.; Nava, J.L. Influence of the anode material on the degradation of naproxen by Fenton-based electrochemical processes. Chem. Eng. J. 2016, 304, 817-825. [CrossRef]

30. Vidal, J.; Huiliñir, C.; Santander, R.; Silva-Agredo, J.; Torres-Palma, R.A.; Salazar, R. Effective removal of the antibiotic Nafcillin from water by combining the Photoelectro-Fenton process and Anaerobic Biological Digestion. Sci. Total Environ. 2018, 624, 1095-1105. [CrossRef]

31. Moreira, F.C.; Boaventura, R.A.R.; Brillas, E.; Vilar, V.J.P. Electrochemical advanced oxidation processes: A review on their application to synthetic and real wastewaters. Appl. Catal. B Environ. 2017, 202, 217-261. [CrossRef]

32. Yavuz, Y.; Shahbazi, R. Anodic oxidation of Reactive Black 5 dye using boron doped diamond anodes in a bipolar trickle tower reactor. Sep. Purif. Technol. 2012, 85, 130-136. [CrossRef]

33. Candia-Onfray, C.; Thiam, A.; Salazar, C.; Martinez-Huitle, C.A.; Salazar, R. Enhanced degradation of the industrial textile dye disperse red BG by electrochemical process with different anodes. J. Electrochem. Soc. 2017, 164, E440. [CrossRef]

34. Bruguera-Casamada, C.; Sirés, I.; Brillas, E.; Araujo, R.M. Effect of electrogenerated hydroxyl radicals, active chlorine and organic matter on the electrochemical inactivation of Pseudomonas aeruginosa using BDD and dimensionally stable anodes. Sep. Purif. Technol. 2017, 178, 224-231. [CrossRef]

35. Ribeiro, F.W.P.; Oliveira, S.d.N.; Lima Neto, P.d.; Correia, A.N.; Mascaro, L.H.; Matos, R.D.; de Souza, E.; Lanza, M.D.V. Electrodegradation of Ponceau 2R using dimensionally-stable anodes and Ti/Pt. Quim. Nova 2013, 36, 85-90. [CrossRef]

36. Jara, C.C.; Fino, D.; Specchia, V.; Saracco, G.; Spinelli, P. Electrochemical removal of antibiotics from wastewaters. Appl. Catal. B Environ. 2007, 70, 479-487. [CrossRef]

37. Rice, E.W.; Baird, R.B.; Eaton, A.D.; Clesceri, L.S. Standard Methods for the Examination of Water and Wastewater, 22nd ed.; American Water Works Association: Denver, CO, USA, 2012.

38. Government of Chile. NMP Procedure for the Determination of Fecal Coliforms in Waters by Method A1; PRT-712.02e006; Government of Chile: Santiago de Chile, Chile, 1992.

39. Ioannou, L.A.; Li Puma, G.; Fatta-Kassinos, D. Treatment of winery wastewater by physicochemical, biological and advanced processes: A review. J. Hazard Mater. 2015, 286, 343-368. [CrossRef]

40. Moreira, F.C.; Boaventura, R.A.; Brillas, E.; Vilar, V.J. Remediation of a winery wastewater combining aerobic biological oxidation and electrochemical advanced oxidation processes. Water Res. 2015, 75, 95-108. [CrossRef]

41. Bolzonella, D.; Rosso, D. Proceedings of the 6th IWA Conference on Viticulture and Winery Wastes, Narbonne, France, 26-30 May 2013.

42. Amor, C.; Marchão, L.; Lucas, M.S.; Peres, J.A. Application of advanced oxidation processes for the treatment of recalcitrant agro-industrial wastewater: A review. Water 2019, 11, 205. [CrossRef]

43. Amaral-Silva, N.; Martins, R.C.; Paiva, C.; Castro-Silva, S.; Quinta-Ferreira, R.M. A new winery wastewater treatment approach during vintage periods integrating ferric coagulation, Fenton reaction and activated sludge. J. Environ. Chem. Eng. 2016, 4 , 2207-2215. [CrossRef]

44. Montalvo, S.; Guerrero, L.; Borja, R.; Cortés, I.; Sánchez, E.; Colmenarejo, M. Effect of the influent COD concentration on the anaerobic digestion of winery wastewaters from grape-red and tropical fruit (guava) wine production in fluidized bed reactors with Chilean natural zeolite for biomass immobilization. Chem. Biochem. Eng. Q. 2010, 24, 219-226.

45. Braz, R.; Pirra, A.; Lucas, M.S.; Peres, J.A. Combination of long term aerated storage and chemical coagulation/flocculation to winery wastewater treatment. Desalination 2010, 263, 226-232. [CrossRef]

46. Milani, M.; Consoli, S.; Marzo, A.; Pino, A.; Randazzo, C.; Barbagallo, S.; Cirelli, G.L. Treatment of winery wastewater with a multistage constructed wetland system for irrigation reuse. Water 2020, 12, 1260. [CrossRef]

47. Zorpas, A.; Saranti, A. Multi-criteria analysis of sustainable environmental clean technologies for the treatment of winery's wastewater. Int. J. Glob. Environ. Issues 2016, 15, 151-168. [CrossRef]

48. Collivignarelli, M.C.; Abbà, A.; Miino, M.C.; Arab, H.; Bestetti, M.; Franz, S. Decolorization and biodegradability of a real pharmaceutical wastewater treated by $\mathrm{H}_{2} \mathrm{O}_{2}$-assisted photoelectrocatalysis on $\mathrm{TiO}_{2}$ meshes. J. Hazard. Mater. 2020, 387,121668 . [CrossRef]

49. Garcia-Segura, S.; Brillas, E. Mineralization of the recalcitrant oxalic and oxamic acids by electrochemical advanced oxidation processes using a boron-doped diamond anode. Water Res. 2011, 45, 2975-2984. [CrossRef] [PubMed]

50. Garcia-Segura, S.; Cavalcanti, E.B.; Brillas, E. Mineralization of the antibiotic chloramphenicol by solar photoelectro-Fenton: From stirred tank reactor to solar pre-pilot plant. Appl. Catal. B Environ. 2014, 144, 588-598. [CrossRef]

51. El-Ghenymy, A.; Cabot, P.L.; Centellas, F.; Garrido, J.A.; Rodríguez, R.M.; Arias, C.; Brillas, E. Mineralization of sulfanilamide by electro-Fenton and solar photoelectro-Fenton in a pre-pilot plant with a Pt/air-diffusion cell. Chemosphere 2013, 91, 1324-1331. [CrossRef] [PubMed]

52. Welz, P.J.; Holtman, G.; Haldenwang, R.; le Roes-Hill, M. Characterisation of winery wastewater from continuous flow settling basins and waste stabilisation ponds over the course of 1 year: Implications for biological wastewater treatment and land application. Water Sci. Technol. 2016, 74, 2036-2050. [CrossRef] 
53. Salmerón, I.; Oller, I.; Malato, S. Electro-oxidation process assisted by solar energy for the treatment of wastewater with high salinity. Sci. Total Environ. 2020, 705, 135831. [CrossRef]

54. Lan, Y.; Coetsier, C.; Causserand, C.; Serrano, K.G. On the role of salts for the treatment of wastewaters containing pharmaceuticals by electrochemical oxidation using a boron doped diamond anode. Electrochim. Acta 2017, 231, 309-318. [CrossRef] 